\title{
SMOKING BEHAVIORS AND ATTITUDES TOWARDS THE SMOKE-FREE CAMPUS POLICY: A SYSTEMATIC REVIEW
}

\author{
Shazwani Mohmad ${ }^{1}$ and Aniza Ismail ${ }^{1}$ \\ ${ }^{1}$ Department of Community Health, Faculty of Medicine, UKM Medical Centre, 56000 Kuala Lumpur, Malaysia.
}

Corresponding author: Aniza Ismail

E-mail: aniza@ppukm.ukm.edu.my

\begin{abstract}
We conducted this systematic review to document the published literature related to smoking behaviors and attitudes towards the smoke-free campus policy. Studies on universities that had implemented the smoke-free campus policy were included in this review. The search for published articles from January 2010 to December 2020 involved three main electronic databases: Ovid MEDLINE, ScienceDirect, and Scopus. We searched the databases with the following Boolean string: [(smoke-free OR tobacco-free) AND (campus OR university OR college) AND (knowledge* OR attitude* OR practice*)]. Seventeen studies were included in this review. The majority $(n=8)$ were from the United States, followed by Saudi Arabia $(n=2)$ and one each from Israel, Lebanon, Australia, Canada, the United Kingdom, Spain, and China. Eight studies reported a positive impact of the policy on smoking behavior (plan to quit smoking, attempt to quit smoking, reduce smoking). However, 11 studies reported that respondents were still exposed to second-hand smoke and that cigarette butts were still scattered around the university area. Nine studies reported negative attitudes towards smoking, and seven of 12 studies reported positive attitudes towards the policy. Overall, the smoke-free campus policy had mixed impacts. Nevertheless, we found that attitude towards a smoke-free campus and smoking behavior has a good impact.
\end{abstract}

Keywords: Smoke-free, university, policy, second-hand smoke, smoking

\section{INTRODUCTION}

It has been estimated that there are more than 1.1 billion smokers worldwide, with an estimated 945 million male smokers as compared to 180 million female smokers ${ }^{1}$. Various studies have proven that tobacco usage can harm human health and that it is the main reason for premature, preventable death ${ }^{2,3}$. Tobacco usage causes 7 million deaths every year ${ }^{4}$, and if the trend of tobacco usage remains until 2030, more than 8 million people will perish yearly from diseases related to tobacco usage ${ }^{5}$.

To prevent tobacco usage from gradually becoming a health crisis, the World Health Organization (WHO) established the Framework Convention on Tobacco Control (FCTC) to protect current and future generations from the negative impact of tobacco usage and to reduce secondhand smoke (SHS) to the public ${ }^{6,7}$. The establishment of smoke-free areas has the potential to reduce tobacco usage in public areas, encourage smokers to quit, reduce SHS, and establish conducive environments 8,9 . Universities are one of the zones declared as smoke-free areas.

In 2018, $13.7 \%$ of United States citizens (equivalent to 34.2 million people) aged $\geq 18$ years were smokers, and smokers aged 25-44 years comprised the highest percentage thereof ${ }^{10}$. Smoking among youth is very alarming and worrying for public health. A study conducted in the US reported almost all smokers (98\%) started smoking before the age of 26 years ${ }^{11}$. This scenario has made universities a relevant location for preventing smoking and aiding smokers in quitting their addiction at the early stage of life. Quitting smoking before the age of 30 years, as compared to continuing to smoke, can reduce the risk of developing lung cancer by more than $90 \%{ }^{12}$.

Since 2012, the number of universities that have implemented the smoke-free campus policy has increased every year ${ }^{13}$. Up until July 1,2020 , at least 2,511 US universities had a smoke-free campus policy and had banned all smoking-related activities from the entire campus ${ }^{14}$. This policy has produced a conducive environment for university residents regardless of whether they are smokers or non-smokers. The policy establishes an environment that helps smokers reduce cigarette consumption and subsequently encourages them to quit smoking. Thus, reducing or banning smoking activities in university helps to protect non-smokers.

One of the main theories related to policy compliance with the smoke-free campus is the theory of planned behavior (TPB) ${ }^{15}$. According to the TPB ${ }^{16,17}$, intention is the possibility that will influence the behavior, and is the most important indicator in predetermining the behavior. Intention is indicated by a combination of three global factors: attitude toward action, perceived 
normative pressure, and perceived behavioral control $^{18}$. Compliance with the smoke-free policy requires the following three factors: positive attitudes towards a smoke-free campus policy, negative attitudes towards smoking, and positive smoking behavior.

Here, we conducted the present review to document published studies on the attitudes and behaviors towards the smoke-free campus policy. Understanding such attitudes and behaviors can aid policymakers and researchers in escalating the effectiveness of the policy for the benefit and well-being of all university residents.

\section{METHODS}

We conducted a systematic review of the academic literature to identify published information on the behaviors and attitudes towards the smoke-free campus policy. We followed the structure of the Preferred Reporting Items for Systematic Reviews and Meta-Analyses (PRISMA) statement and used the PICO (Population, Intervention, Comparator, Outcome) methodology ${ }^{19}$. The search involved three main electronic databases: Ovid MEDLINE, ScienceDirect, and Scopus. These databases were selected because they primarily contain articles covering subject areas relevant to the topic being investigated: public health, healthcare sciences, and social behavior, and our university is subscribed to them. We searched the databases with the following Boolean string: [(smoke-free OR tobacco-free) AND (campus OR university OR college) AND (knowledge* OR attitude* OR practice*)]. The systematic search for published articles was verified in January 2010 to December 2020.

The database search returned a total of 2,579 studies: 259 from ScienceDirect, 271 from Scopus, and 2,049 from Ovid MEDLINE (Fig 1). A total of 35 duplicate studies were identified, leaving a total of 2,544 studies. The title and abstract of each study were screened according to the inclusion and exclusion criteria. Studies were excluded if they were written in languages other than English. In this review, both qualitative and quantitative studies on university residents' attitudes and behaviors towards a smoke-free campus policy were included. The target group was required to involve both smoking and non-smoking university students. Only universities that had implemented the smoke-free campus policy were included in this study. The selected studies had to have measured both the impact of smoking behaviors and attitudes towards smoking or a smoke-free campus policy. Systematic reviews, commentaries, essays, and consensus statements were excluded from this review.

We excluded a further 2,493 titles and abstracts unrelated to the attitudes and behaviors towards the smoke-free campus policy from this study. The full text of 51 studies was included for further evaluation. We read the full text of these studies and made independent decisions regarding their inclusion or exclusion based on the above criteria. Of the 51 studies, 34 did not specifically evaluate the attitudes and behaviors towards the policy, and were excluded. Figure 1 shows the article selection flow diagram.

\section{Methodological quality}

All authors evaluated each study, and consensus was required to ensure and guarantee the quality of the study chosen. The main flaw of the selected studies was self-reporting, on which 17 studies were based and which can influence and create biased responses. Further, the ability to generalize study outcomes required consideration because most of the study locations selected were limited to specific locations (i.e., only involved one department or one campus or one university). Eight studies used simple random sampling that induced bias ${ }^{20-27}$, seven studies had low response rates $^{20,22,24,25,28-30}$, and two studies did not state the study limitations ${ }^{23,31}$. 


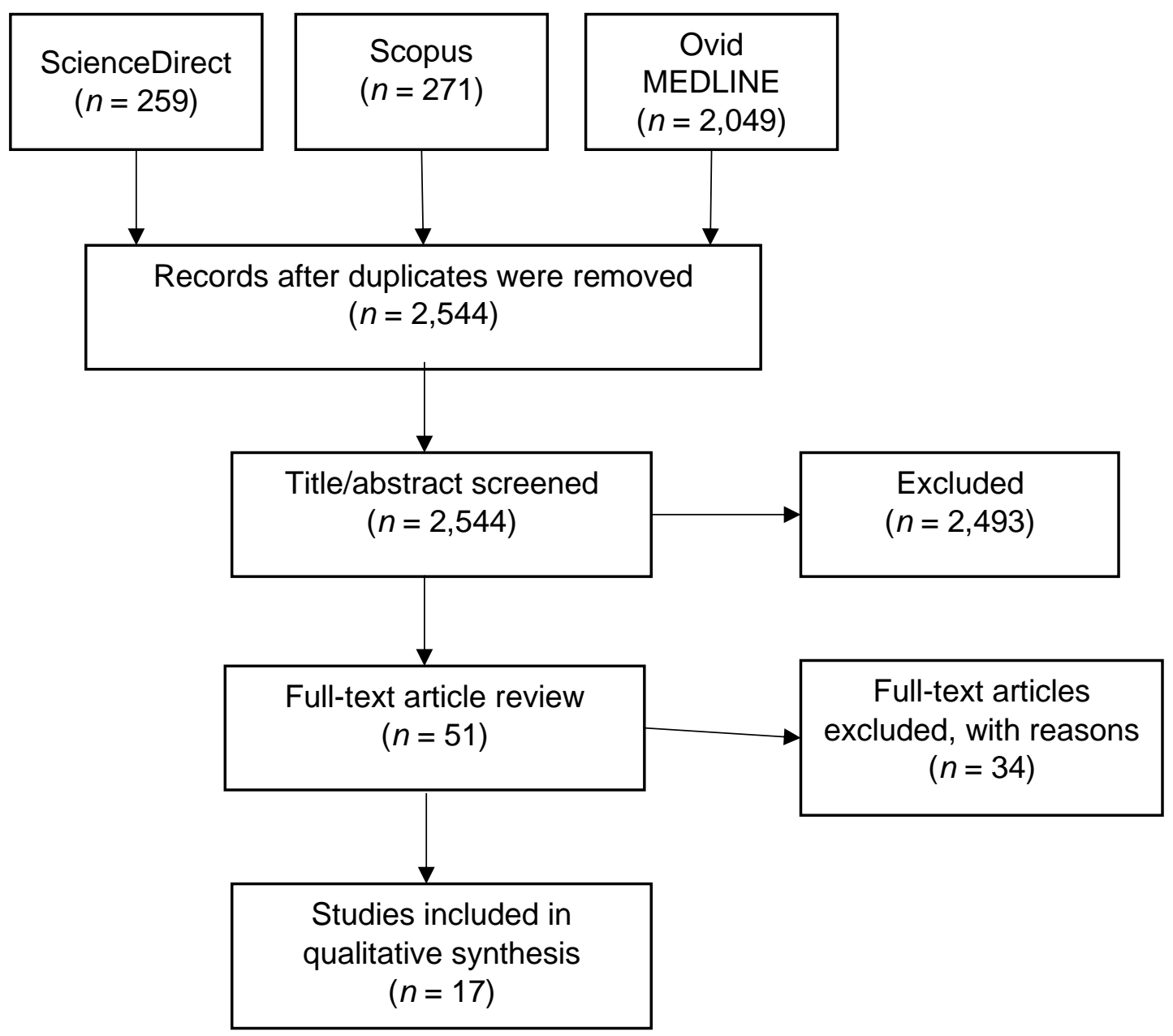

Figure 1. PRISMA diagram of the study selection process.

\section{RESULTS}

Table 1 summarizes the articles selected in this review with regard to the attitudes and behaviors towards the smoke-free campus policy, and other impacts. Table 2 shows a summary of the variables reviewed in the selected articles. According to the Table 1 and Table 2, all seventeen studies measured smoking behavior. Eight out of seventeen studies had positive impact, six studies reported negative impact, and other studies reported mixed results. Eleven studies investigating SHS exposure reported that respondents were still exposed to SHS in university. Seven of the twelve studies that measured attitudes toward smoke-free campus policy reported positive attitudes toward the policy. There were ten studies that measured attitudes towards smoking reported negative impact. In addition, all twelve studies that measured support for smoke-free campus reported positive support. Two studies that measured behavior towards smoking reported negative impact, and three studies that assessed awareness of smoke-free campus policy reported higher awareness among respondents.

\section{DISCUSSION}

The smoke-free campus policy is a practical initiative for the sustainability and well-being of the university neighborhood. Studying the impact of the smoke-free campus policy and evaluating previous studies can increase understanding of the impact and university resident compliance with the policy. The evaluation of the selected studies showed diverse impacts of the policy on university residents. Regarding the impact of attitudes towards the smoke-free campus policy, seven out of twelve studies reported positive attitudes $22,24,27-29,31,36$. The respondents felt that the policy could contribute to a positive impact on health and keep the campus clear of cigarette butts. The establishment of the smoke-free campus policy can elevate the university's image to the public ${ }^{24,30}$. Nevertheless, two studies reported negative attitudes towards the policy ${ }^{25,26}$. In those studies, the respondents felt that the policy created a negative stigma against smokers and denied smokers' individual rights. The respondents also believed that smokers would not obey the rules and that enforcing the policy would burden the university's enforcement officers ${ }^{30}$. 
Table 1. A summary of studies included in the review.

\begin{tabular}{|c|c|c|c|c|c|}
\hline Author & Study description & $\begin{array}{l}\text { Country } \\
\text { of origin }\end{array}$ & Objectives & Outcomes & Limitations \\
\hline $\begin{array}{l}\text { Wong et al. } \\
(2020)^{20}\end{array}$ & 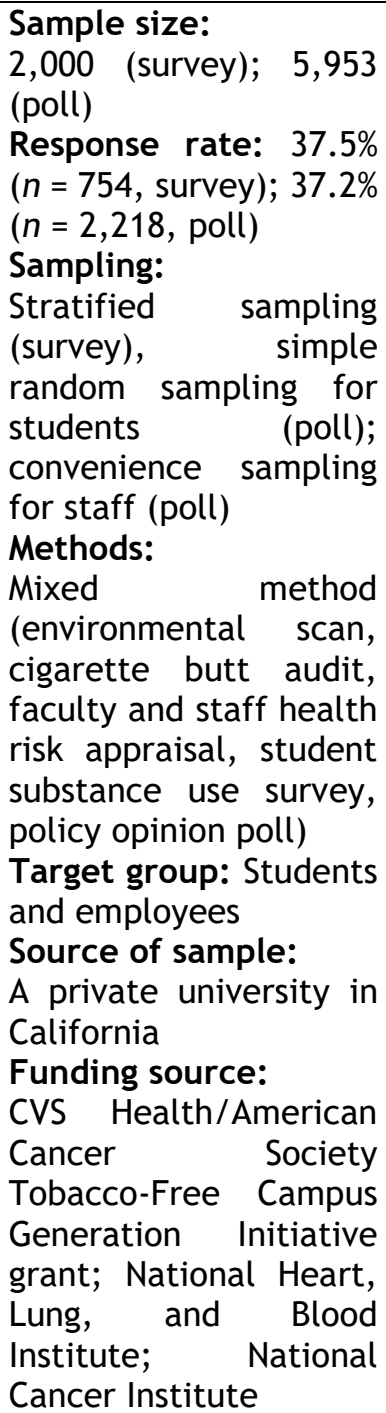 & US & $\begin{array}{l}\text { Assess cigarette and e- } \\
\text { cigarette use and } \\
\text { characterize the } \\
\text { climate for adopting a } \\
\text { comprehensive } \\
\text { tobacco-free policy }\end{array}$ & $\begin{array}{l}\text { SHS exposure: } \\
\text { In the past } 30 \text { days, SHS exposure was none ( } 43 \%) \text { and } 1-3 \\
\text { times ( } 43 \%) \\
\text { Attitudes towards a smoke-free campus: } \\
\text { Most respondents endorsed the benefits of supporting } \\
\text { health, ensuring tobacco-free air to breathe, reducing } \\
\text { litter, preventing tobacco use and fires, and helping } \\
\text { tobacco users quit. In contrast, the majority of } \\
\text { respondents was concerned about stigmatizing smoking, } \\
\text { personal freedoms, or the start of a slippery slope } \\
\text { Smoking behavior: } \\
\text { Findings indicate low tobacco use prevalence among the } \\
\text { campus community, yet a large volume of butt litter was } \\
\text { found on campus; tobacco clean-up costs were high } \\
\text { Support for a smoke-free campus: } \\
\text { The majority of respondents favored a campus-wide } \\
\text { tobacco-free policy }\end{array}$ & $\begin{array}{l}\text { Low response rate; some } \\
\text { parts of sampling were } \\
\text { convenience sampling. } \\
\text { Observing people smoking } \\
\text { could alter their behavior. } \\
\text { Limited generalization of } \\
\text { the study because it only } \\
\text { focused on one private } \\
\text { university campus }\end{array}$ \\
\hline $\begin{array}{l}\text { Feldman } \\
(2016)^{21}\end{array}$ et al. & $\begin{array}{l}\text { Sample size: } \\
449 \\
\text { Response rate: } \\
72.5 \%(n=313)\end{array}$ & Israel & $\begin{array}{l}\text { Examine smoking } \\
\text { behaviors, cigarette } \\
\text { smoke exposure, and } \\
\text { attitudes towards the }\end{array}$ & $\begin{array}{l}\text { SHS exposure: } \\
\text { Most respondents reported daily exposure or exposure } \\
\text { several times a week } \\
\text { Attitudes towards a smoke-free campus: }\end{array}$ & $\begin{array}{lr}\text { Choice of target } \\
\text { population } \\
\text { Pharmacy } & \text { (School of } \\
\text { students and employees); }\end{array}$ \\
\hline
\end{tabular}




\begin{tabular}{|c|c|c|c|c|c|}
\hline & $\begin{array}{l}\text { Sampling: } \\
\text { Convenience sampling } \\
\text { Methods: } \\
\text { Self-administered } \\
\text { questionnaire } \\
\text { Target group: } \\
\text { Students } \\
\text { employees and } \\
\text { Source of sample: } \\
\text { Hebrew University } \\
\text { Hadassah Ein } \\
\text { Kerem } \\
\text { Funding source: } \\
\text { No external funding }\end{array}$ & & $\begin{array}{l}\text { smoke-free campus } \\
\text { policy among students } \\
\text { and employees }\end{array}$ & $\begin{array}{l}\text { Most respondents (majority was non-smokers) agreed that } \\
\text { smokers should smoke only in outdoor designated areas } \\
\text { and that all campus buildings should be completely } \\
\text { smoke-free. Only a minority agreed that a policy } \\
\text { prohibiting smoking was unfair to smokers } \\
\text { Smoking behavior: } \\
\text { The majority of respondents reported seeing people } \\
\text { smoke in open campus areas and indoors } \\
\text { Support for a smoke-free campus: } \\
\text { Most respondents supported the smoking ban inside } \\
\text { buildings but fewer supported a complete ban of smoking } \\
\text { throughout the campus, including outside areas. Support } \\
\text { for a complete ban on smoking on campus was higher } \\
\text { among non-smokers than among smokers }\end{array}$ & $\begin{array}{l}\text { despite the high response } \\
\text { rate, the results could still } \\
\text { be biased if those who did } \\
\text { not participate had } \\
\text { differing smoking behavior } \\
\text { or attitudes from the } \\
\text { participants }\end{array}$ \\
\hline $\begin{array}{l}\text { Gatto et al. } \\
(2018)^{22}\end{array}$ & $\begin{array}{l}\text { Sample size: Students } \\
(n \quad 40,123) ; \\
\text { faculty/staff }(n= \\
7,884) \\
\text { Response rate: } \\
9.3 \%(n=5,242) \\
\text { Sampling: } \\
\text { Convenience sampling } \\
\text { Methods: } \\
\text { Mixed method (online } \\
\text { survey, counting } \\
\text { cigarette butts found } \\
\text { on the ground, } \\
\text { Geographical System } \\
\text { Information } \\
\text { [GIS] mapping) } \\
\text { Target group: } \\
\text { Students and } \\
\text { employees of sample: } \\
\text { Source ou } \\
\text { University of South } \\
\text { Florida source: } \\
\text { Funding source: } \\
\text { Not mentioned }\end{array}$ & US & $\begin{array}{l}\text { Evaluate the } \\
\text { enforcement, opinions, } \\
\text { and effectiveness of } \\
\text { the university's } \\
\text { tobacco-free } \\
\text { policy } 1 \text { year following } \\
\text { implementation }\end{array}$ & $\begin{array}{l}\text { SHS exposure: } \\
\text { Approximately half of the respondents identified that } \\
\text { they were exposed to SHS following implementation } \\
\text { Attitudes towards a smoke-free campus: } \\
\text { Smokers were less likely than non-smokers to believe the } \\
\text { tobacco-free campus policy had reduced tobacco use } \\
\text { Smoking behavior: } \\
\text { The majority of respondents witnessed tobacco use on } \\
\text { campus. Most smokers were in the stage of change, or not } \\
\text { enforcing the policy and not thinking about doing so, } \\
\text { while the majority of non-smokers was in the pre- } \\
\text { contemplation stage } \\
\text { Behavior towards smoking: } \\
\text { The majority of respondents were in the pre- } \\
\text { contemplation stage (they did not approach the violator } \\
\text { to inform them of the policy and had no intention to do } \\
\text { so in the future for cigarette use, chewing tobacco, and } \\
\text { e-cigarettes). Those who did not approach smoking } \\
\text { violators had multiple reasons, including being unsure if } \\
\text { they should address it and being uncomfortable } \\
\text { Awareness of smoke-free campus policy: } \\
\text { More than half of the respondents correctly identified the } \\
\text { university's smoking policy }\end{array}$ & $\begin{array}{l}\text { For observation methods, } \\
\text { times could not be } \\
\text { randomized due to the } \\
\text { volunteers' schedule } \\
\text { limitations, and data were } \\
\text { only collected during } \\
\text { daylight hours due to } \\
\text { safety concerns. There } \\
\text { was a limit to the } \\
\text { information available on } \\
\text { violators, and the ArcGIS } \\
\text { observations, } \\
\text { smokeless tobacco, leaves } \\
\text { little observation evidence } \\
\text { of use or disposal; the } \\
\text { study used convenience } \\
\text { sampling }\end{array}$ \\
\hline Almutairi (2014) & $\begin{array}{l}\text { Sample size: } \\
4,591 \\
\text { Response rate: } \\
\text { Not applicable } \\
\end{array}$ & $\begin{array}{l}\text { Saudi } \\
\text { Arabia }\end{array}$ & $\begin{array}{l}\text { Compare the } \\
\text { prevalence of smoking } \\
\text { among students, } \\
\text { faculty, and staff; }\end{array}$ & $\begin{array}{l}\text { Attitudes towards smoking: } \\
\text { The majority of respondents (mostly non-smokers) agreed } \\
\text { with the effects of smoking if someone smoked around } \\
\text { them. Non-smokers were least likely to agree that }\end{array}$ & $\begin{array}{l}\text { Limited generalizability } \\
\text { (only involved the KSU } \\
\text { community); the study was } \\
\text { based on self-reporting }\end{array}$ \\
\hline
\end{tabular}




\begin{tabular}{|c|c|c|c|}
\hline & $\begin{array}{l}\text { Sampling: } \\
\text { Random sampling } \\
\text { Methods: } \\
\text { Self-administered } \\
\text { questionnaire } \\
\text { Target group: } \\
\text { Students and staff } \\
\text { Source of sample: } \\
\text { King Saud University } \\
\text { (KSU) } \\
\text { Funding source: } \\
\text { Research Centre at the } \\
\text { College of Applied } \\
\text { Medical Sciences and } \\
\text { the } \\
\text { Deanship of Scientific } \\
\text { Research at KSU }\end{array}$ & $\begin{array}{l}\text { examine their interest } \\
\text { to quit; determine } \\
\text { the difference in } \\
\text { perceptions of smoking } \\
\text { and non-smoking } \\
\text { students, faculty, and } \\
\text { staff with regard to } \\
\text { implementation of a } \\
\text { smoke-free policy }\end{array}$ & $\begin{array}{l}\text { smoking is a personal freedom, and almost all smokers } \\
\text { agreed with this statement } \\
\text { Smoking behavior: } \\
\text { About half of the smokers within the university had } \\
\text { attempted to quit smoking } \\
\text { Support for a smoke-free campus: } \\
\text { The majority of respondents were supportive of a smoke- } \\
\text { free policy and indicated that it should be strictly } \\
\text { enforced, especially in public places. Smokers were more } \\
\text { likely to support a smoke-free policy if there were no fines } \\
\text { or penalties }\end{array}$ \\
\hline $\begin{array}{l}\text { Chaaya } \\
(2015)^{31}\end{array}$ et al. & 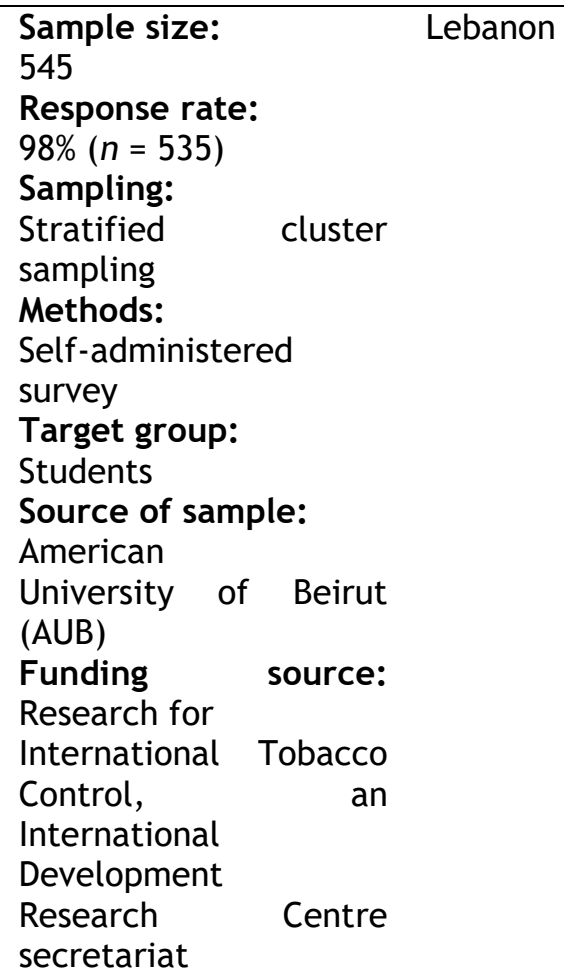 & $\begin{array}{l}\text { Examine students' } \\
\text { compliance and } \\
\text { attitudes } \\
\text { following the campus } \\
\text { non-smoking policy }\end{array}$ & $\begin{array}{l}\text { Attitudes towards a smoke-free campus: } \\
\text { The majority of respondents were satisfied to a large } \\
\text { extent with the ban and considered it justified. Only a } \\
\text { minority reported that the ban would help reduce } \\
\text { smoking to a large extent or that it would help smokers } \\
\text { quit. Most respondents thought that the ban contributed } \\
\text { somewhat or to a large extent to creating a healthy } \\
\text { environment } \\
\text { Smoking behavior: } \\
\text { The majority of respondents agreed that the ban would } \\
\text { help smokers decrease smoking but would have no effect } \\
\text { on cessation } \\
\text { Support for a smoke-free campus: } \\
\text { Only } 45 \% \text { of non-smokers supported AUB becoming } \\
\text { entirely smoke-free, as opposed to only } 10.2 \% \text { of regular } \\
\text { smokers }\end{array}$ \\
\hline
\end{tabular}




\begin{tabular}{|c|c|c|c|c|c|}
\hline $\begin{array}{l}\text { Burns } \\
(2016)^{28}\end{array}$ & $\begin{array}{l}\text { Sample size: } \\
\text { 5,000 } \\
\text { Response rate: } \\
\text { Before: } 19.4 \%(n=969) \\
\text { After } 1 \text { year: } 13.4 \%(n= \\
670) \\
\text { Sampling: } \\
\text { Random sampling } \\
\text { Methods: } \\
\text { Emailed survey } \\
\text { Target group: } \\
\text { Students and staff } \\
\text { Source of sample: } \\
\text { A large Western } \\
\text { Australian university } \\
\text { Funding source: } \\
\text { Not mentioned }\end{array}$ & Australia & $\begin{array}{l}\text { Evaluate a total } \\
\text { smoking ban at a large } \\
\text { Australian university }\end{array}$ & $\begin{array}{l}\text { SHS exposure: } \\
\text { SHS exposure was reduced significantly } 1 \text { year after policy } \\
\text { implementation, but only a minority had never been } \\
\text { exposed to SHS, indicating that SHS exposure remained } \\
\text { present } \\
\text { Attitudes towards a smoke-free campus: } \\
\text { There was a significant increase in positive responses to } \\
\text { the statement that the campus should be totally smoke- } \\
\text { free } 1 \text { year after policy implementation } \\
\text { Attitudes towards smoking: } \\
\text { General attitudes were negative. } \\
\text { Smoking behavior: } \\
\text { Smoking prevalence was similar for both periods; over } \\
\text { half of the smokers indicated that they were planning to } \\
\text { quit smoking in the future } \\
\text { Support for a smoke-free campus: } \\
\text { There was strong support that all campus buildings should } \\
\text { be smoke-free during both periods } \\
\text { Awareness of smoke-free campus policy: } \\
\text { Increased significantly } 1 \text { year after policy implementation }\end{array}$ & $\begin{array}{l}\text { The cross-sectional nature } \\
\text { of the study precluded any } \\
\text { causal effects; the low } \\
\text { proportion of smokers who } \\
\text { participated in the survey } \\
\text { may have been due to } \\
\text { selective non-reporting or } \\
\text { under-reporting and the } \\
\text { low response rate }\end{array}$ \\
\hline $\begin{array}{lll}\text { Lechner } & \text { et } & \text { al. } \\
(2014)^{33} & & \end{array}$ & $\begin{array}{l}\text { Sample size: } \\
\text { Baseline: } 1,119 \\
\text { 2008: } 1,178 \\
\text { 2009: } 1,237 \\
\text { 2010: } 1,242 \\
\text { Response rate: } \\
\text { Not applicable } \\
\text { Sampling: } \\
\text { Cluster sampling } \\
\text { Methods: } \\
\text { Self-report } \\
\text { questionnaire } \\
\text { Target group: } \\
\text { Students } \\
\text { Source of sample: } \\
\text { A large Midwestern } \\
\text { university } \\
\text { Funding source: } \\
\text { Not mentioned }\end{array}$ & US & $\begin{array}{l}\text { Examine the } \\
\text { effectiveness of a } \\
\text { campus-wide anti- } \\
\text { tobacco program using } \\
\text { pre-post data across a } \\
\text { 4-year period. Smoking } \\
\text { prevalence, } \\
\text { behaviors, attitudes, } \\
\text { and beliefs were } \\
\text { assessed via self-report } \\
\text { at four time points }\end{array}$ & $\begin{array}{l}\text { SHS exposure: } \\
\text { Respondents reported significant decreases in SHS } \\
\text { exposure immediately after the ban and campaign were } \\
\text { initiated } \\
\text { Attitudes towards smoking: } \\
\text { Respondents' beliefs about nicotine's ability to serve as a } \\
\text { weight loss supplement decreased over time; preference } \\
\text { for socializing in a smoke-free environment increased } \\
\text { significantly following the ban } \\
\text { Smoking behavior: } \\
\text { The percentage of more frequent smokers and less } \\
\text { frequent smokers decreased across assessment points. }\end{array}$ & $\begin{array}{l}\text { The lack of a control } \\
\text { campus for comparison; } \\
\text { the lack of data available } \\
\text { to confirm the stability of } \\
\text { some of the significant } \\
\text { trends reported; the lack } \\
\text { of the inclusion of a } \\
\text { biological measure (such } \\
\text { as cotinine) to confirm the } \\
\text { accuracy of the decline in } \\
\text { self-reported smoking }\end{array}$ \\
\hline $\begin{array}{l}\text { Butler } \\
(2012)^{29}\end{array}$ et al. & $\begin{array}{l}\text { Sample size: } \\
1,700 \\
\text { Response rate: }\end{array}$ & US & $\begin{array}{l}\text { Assess attitudes and } \\
\text { behaviors related to } \\
\text { the smoke-free policy }\end{array}$ & $\begin{array}{l}\text { Attitudes towards a smoke-free campus: } \\
\text { The majority of respondents living on campus as } \\
\text { compared to those living off campus rated the policy as }\end{array}$ & $\begin{array}{l}\text { The low response rate and } \\
\text { the overrepresentation of } \\
\text { women in the full sample }\end{array}$ \\
\hline
\end{tabular}




\begin{tabular}{|c|c|c|c|c|}
\hline & $\begin{array}{l}30 \%(n=360) \\
\text { Sampling: } \\
\text { Random sampling } \\
\text { Methods: } \\
\text { Emailed survey } \\
\text { Target group: } \\
\text { Students } \\
\text { Source of sample: } \\
\text { A public university in } \\
\text { the South } \\
\text { Funding source: } \\
\text { National Centre for } \\
\text { Research Resources, } \\
\text { Office of the Director, } \\
\text { National Institutes of } \\
\text { Health (NIH); supported } \\
\text { by the NIH Roadmap for } \\
\text { Medical Research }\end{array}$ & $\begin{array}{l}\text { among undergraduate } \\
\text { students and alcohol } \\
\text { drinkers on a campus in } \\
\text { a community with } \\
\text { smoke-free bars }\end{array}$ & $\begin{array}{l}\text { "very important". Only a smaller percentage of current } \\
\text { smokers compared with non-smokers rated the smoke- } \\
\text { free campus policy as "very important" } \\
\text { Smoking behavior: } \\
\text { The majority of smokers said the smoke-free law had no } \\
\text { effect on their motivation to quit smoking and no effect } \\
\text { on the number of cigarettes they smoked daily } \\
\text { Support for a smoke-free campus: } \\
\text { Overall, there was support for the policy in campus } \\
\text { buildings }\end{array}$ & $\begin{array}{l}\text { and in the subsample of } \\
\text { alcohol users }\end{array}$ \\
\hline $\begin{array}{l}\text { Gauthier et al. } \\
(2013)^{23}\end{array}$ & $\begin{array}{l}\text { Sample size: } \\
1,282 \\
\text { Response rate: } \\
\text { Not applicable } \\
\text { Sampling: } \\
\text { Convenience sampling } \\
\text { Methods: } \\
\text { Online survey } \\
\text { Target group: } \\
\text { Students, employees, } \\
\text { contract workers } \\
\text { Source of sample: } \\
\text { Laurentian University } \\
\text { Funding source: } \\
\text { None }\end{array}$ & $\begin{array}{l}\text { Gain a better sense of } \\
\text { the prevalence } \\
\text { of smoking and SHS } \\
\text { exposure in a } \\
\text { geographically isolated } \\
\text { post-secondary } \\
\text { context; assess the } \\
\text { awareness of existing } \\
\text { non-smoking } \\
\text { initiatives; identify } \\
\text { preferred approaches } \\
\text { for tobacco control }\end{array}$ & $\begin{array}{l}\text { SHS exposure: } \\
\text { The majority of respondents reported that they had been } \\
\text { exposed to SHS in the past month on campus } \\
\text { Attitudes towards smoking: } \\
\text { Most respondents (majority was non-smokers) said that } \\
\text { being exposed to cigarette smoke bothered them. Half of } \\
\text { the respondents felt that smoking should only be allowed } \\
\text { in designated outdoor smoking areas; some felt that } \\
\text { smoking should not be allowed anywhere on campus; only } \\
\text { a minority felt that smoking should be allowed anywhere } \\
\text { outdoors on campus } \\
\text { Smoking behavior: } \\
\text { The majority of smokers had tried to quit smoking; most } \\
\text { indicated they planned to quit within the } \\
\text { next year. Only a few smokers felt that further } \\
\text { restrictions on campus would increase their likelihood of } \\
\text { quitting } \\
\text { Behavior towards smoking: } \\
\text { Only a minority of respondents had ever actually asked } \\
\text { someone to stop smoking in their presence }\end{array}$ & Not mentioned \\
\hline $\begin{array}{l}\text { Ramachandran et } \\
\text { al. }(2020)^{34}\end{array}$ & $\begin{array}{l}\text { Sample size: } \\
1,704 \\
\text { Response rate: } \\
93 \%(n=1,541) \\
\end{array}$ & $\begin{array}{l}\text { Estimate the } \\
\text { prevalence of smoking } \\
\text { behavior on campus; } \\
\text { identify the key factors }\end{array}$ & $\begin{array}{l}\text { SHS exposure: } \\
\text { The majority of respondents reported being exposed to } \\
\text { SHS on campus at least once; some reported altering their } \\
\text { walk on campus to avoid cigarette smoke }\end{array}$ & $\begin{array}{l}\text { This study used self- } \\
\text { reporting and also did not } \\
\text { delineate the use of e- } \\
\text { cigarettes and regular }\end{array}$ \\
\hline
\end{tabular}




\begin{tabular}{|c|c|c|c|c|c|}
\hline & $\begin{array}{l}\text { Sampling: } \\
\text { Random sampling } \\
\text { Methods: } \\
\text { Self-administered } \\
\text { survey } \\
\text { Target group: } \\
\text { Students } \\
\text { Source of sample: } \\
\text { University of Mississippi } \\
\text { Funding source: } \\
\text { Not mentioned }\end{array}$ & & $\begin{array}{l}\text { that influence } \\
\text { adherence to a campus } \\
\text { smoke-free policy }\end{array}$ & $\begin{array}{l}\text { Attitudes towards smoking: } \\
\text { Non-smokers had more negative attitudes towards } \\
\text { smoking than smokers } \\
\text { Smoking behavior: } \\
\text { More than half of the smokers reported still smoking on } \\
\text { campus. The majority of respondents reported witnessing } \\
\text { someone smoking on campus } \\
\text { Support for a smoke-free campus: } \\
\text { Non-smokers had higher negative scores than smokers in } \\
\text { supporting a smoke-free campus }\end{array}$ & $\begin{array}{l}\text { cigarettes. Although a } \\
\text { large sample was } \\
\text { obtained, these data were } \\
\text { collected } 4 \text { years ago; } \\
\text { some of the findings may } \\
\text { have changed since then. } \\
\text { Finally, generalization to } \\
\text { other universities must be } \\
\text { made with caution }\end{array}$ \\
\hline $\begin{array}{l}\text { Gong et al. } \\
(2016)^{35}\end{array}$ & $\begin{array}{l}\text { Sample size: } \\
711 \\
\text { Response rate: } \\
\text { Not applicable } \\
\text { Sampling: } \\
\text { Multistage sampling } \\
\text { Methods: } \\
\text { Internet survey } \\
\text { Target group: } \\
\text { Students sample: } \\
\text { Source of sam } \\
37 \text { colleges in Beijing } \\
\text { Funding source: } \\
\text { National Natural } \\
\text { Science Foundation of } \\
\text { China }\end{array}$ & China & $\begin{array}{l}\text { Evaluate the } \\
\text { implementation of the } \\
\text { Tobacco-Free Campus } \\
\text { Policy (TFCP) in Beijing }\end{array}$ & $\begin{array}{l}\text { SHS exposure: } \\
\text { The majority of respondents were exposed to SHS on } \\
\text { campus at least once in the past month } \\
\text { Attitudes towards smoking: } \\
\text { Most respondents were aware of the harms but only a few } \\
\text { respondents tried to stop their last SHS exposure indoors } \\
\text { and outdoors } \\
\text { Smoking behavior: } \\
\text { The majority of both smokers and non-smokers reported } \\
\text { seeing a teacher and classmate smoking in campus } \\
\text { buildings }\end{array}$ & $\begin{array}{l}\text { This study was based on } \\
\text { convenience sampling; the } \\
\text { majority of respondents } \\
\text { were from college } \\
\text { campuses, which have } \\
\text { upper bounds for tobacco } \\
\text { control measures in China; } \\
\text { this was a descriptive } \\
\text { study designed to track } \\
\text { TFCP implementation } \\
\text { from the users' experience } \\
\text { perspective }\end{array}$ \\
\hline $\begin{array}{l}\text { Bartington et al. } \\
(2020)^{24}\end{array}$ & $\begin{array}{l}\text { Sample size: } \\
38,000 \\
\text { Response rate: } \\
2.5 \%(n=934) \\
\text { Sampling: } \\
\text { Convenience sampling } \\
\text { Methods: } \\
\text { Web-based } \\
\text { questionnaire } \\
\text { Target group: } \\
\text { Students and staff } \\
\text { Source of sample: } \\
\text { University } \\
\text { Birmingham of } \\
\text { Funding source: }\end{array}$ & $\begin{array}{l}\text { United } \\
\text { Kingdom }\end{array}$ & $\begin{array}{l}\text { Collect baseline data } \\
\text { among staff and } \\
\text { students; measure } \\
\text { smoking behaviors and } \\
\text { attitudes } \\
\text { towards the } \\
\text { introduction of } \\
\text { campus-wide tobacco } \\
\text { control policies within } \\
\text { a UK higher education } \\
\text { setting }\end{array}$ & $\begin{array}{l}\text { Attitudes towards a smoke-free campus: } \\
\text { The majority of respondents reported that a smoke-free } \\
\text { campus policy would improve staff and student health and } \\
\text { the university's public image. However, the majority of } \\
\text { smokers also felt that the policy would discriminate } \\
\text { against and disadvantage smokers, with fewer non- } \\
\text { smokers considering that it would be a discriminative } \\
\text { policy } \\
\text { Attitudes towards smoking: } \\
\text { The majority of respondents agreed that staff and } \\
\text { students should not be exposed to SHS on campus, } \\
\text { supported the aspiration for a smoke-free university } \\
\text { campus, and endorsed restrictions on tobacco sales }\end{array}$ & $\begin{array}{l}\text { Low response rate, males } \\
\text { were slightly } \\
\text { underrepresented, use of } \\
\text { a self-administered } \\
\text { questionnaire (self- } \\
\text { reported); the element of } \\
\text { selective nonresponse bias } \\
\text { may have resulted in more } \\
\text { positive attitudes towards } \\
\text { tobacco control policies } \\
\text { than among the total } \\
\text { university population }\end{array}$ \\
\hline
\end{tabular}


Smoking behavior:

Almost half of the current smokers reported they wished to quit smoking and almost one-third had attempted to quit within the previous 12 months. However, the majority had smoked on campus

\section{Support for a smoke-free campus:}

Overall, more than half of the respondents supported a smoke-free campus and endorsed restrictions for tobacco sales; just under half of the respondents supported a ban on e-cigarette/vaping device use on campus (the highest level of support was among non-smokers)

\begin{tabular}{|c|c|c|c|c|c|}
\hline $\begin{array}{l}\text { Wray et al. } \\
(2020)^{25}\end{array}$ & $\begin{array}{l}\text { Sample size: } \\
\text { 2016: } 16,829 \\
\text { 2017: } 16,749 \\
\text { Response rate: } \\
\text { 2016: } 13.5 \%(n=2,277) \\
2017: 10.21 \% \quad(n= \\
\text { 1,206) } \\
\text { Sampling: } \\
\text { Convenience sampling } \\
\text { Methods: } \\
\text { Mixed methods (Online } \\
\text { surveys and open- } \\
\text { ended questions in 2017 } \\
\text { survey) and } \\
\text { Target group: } \\
\text { Students enployees } \\
\text { employe } \\
\text { Source of sample: } \\
\text { University of Missouri } \\
\text { Funding source: } \\
\text { None }\end{array}$ & US & $\begin{array}{l}\text { Assess the impact on } \\
\text { tobacco- and policy- } \\
\text { related perceptions } \\
\text { and behaviors }\end{array}$ & $\begin{array}{l}\text { Attitudes towards a smoke-free campus: } \\
\text { policy were low; perceptions that tobacco policies are } \\
\text { hard to enforce were relatively high } \\
\text { Attitudes towards smoking: } \\
\text { Among the respondents, perceived acceptability of } \\
\text { tobacco use was decreased; norms disapproving tobacco } \\
\text { use were increased after policy implementation } \\
\text { Smoking behavior: } \\
\text { Self-reported use of any tobacco decreased after the ban } \\
\text { was enacted } \\
\text { Support for a smoke-free campus: } \\
\text { Policy support and norms disapproving tobacco use on } \\
\text { campus increased }\end{array}$ & $\begin{array}{l}\text { The data were collected } \\
\text { using separate cross- } \\
\text { sectional surveys each } \\
\text { year; all items were self- } \\
\text { reported. The biggest } \\
\text { threat to validity was the } \\
\text { unexpected and large } \\
\text { decline in student } \\
\text { participation in year } \\
2 \text { of the university surveys }\end{array}$ \\
\hline $\begin{array}{l}\text { Bamashmous } \\
(2018)^{26}\end{array}$ & $\begin{array}{l}\text { Sample size: } \\
380 \\
\text { Response rate: } \\
82.4 \%(n=313) \\
\text { Sampling: } \\
\text { Convenience sampling } \\
\text { Methods: } \\
\text { Self-administered } \\
\text { paper-based } \\
\text { questionnaire }\end{array}$ & $\begin{array}{l}\text { Saudi } \\
\text { Arabia }\end{array}$ & $\begin{array}{l}\text { Assess determinants of } \\
\text { support for a smoke- } \\
\text { free } \\
\text { university policy among } \\
\text { dental students, } \\
\text { evaluate } \\
\text { awareness and } \\
\text { compliance with the } \\
\text { policy, assess and } \\
\text { identify factors }\end{array}$ & $\begin{array}{l}\text { SHS exposure: } \\
\text { Less than half of the respondents were exposed to SHS in } \\
\text { the university, their household, and at their friends' } \\
\text { houses } \\
\text { Attitudes towards a smoke-free campus: } \\
\text { Only 38\% thought that this policy was followed or } \\
\text { enforced } \\
\text { Attitudes towards smoking: }\end{array}$ & $\begin{array}{l}\text { Small sample size and } \\
\text { potential recall bias, self- } \\
\text { reporting bias, } \\
\text { social desirability. The } \\
\text { study was limited to } \\
\text { dental students, who } \\
\text { might show different } \\
\text { characteristics from those } \\
\text { of other faculties }\end{array}$ \\
\hline
\end{tabular}




\begin{tabular}{|c|c|c|c|c|}
\hline & $\begin{array}{l}\text { Target group: } \\
\text { Students } \\
\text { Source of sample: King } \\
\text { Abdulaziz University } \\
\text { Funding source: } \\
\text { Not mentioned }\end{array}$ & $\begin{array}{l}\text { affecting support for } \\
\text { the policy }\end{array}$ & $\begin{array}{l}\text { Being non-smokers, women had better knowledge of } \\
\text { smoking hazards and were less lenient in accepting SHS } \\
\text { exposure } \\
\text { Smoking behavior: } \\
\text { About one-fifth of the respondents reported that they } \\
\text { smelled smoke at the university; the majority saw } \\
\text { cigarette filters on the ground at least sometimes; less } \\
\text { than half reported that they were exposed to SHS at } \\
\text { university } \\
\text { Support for a smoke-free campus: } \\
\text { The multivariate model showed a direct relationship of } \\
\text { support for a smoke-free university policy with being a } \\
\text { non-smoker and having greater knowledge of smoking } \\
\text { health hazards } \\
\text { Awareness of smoke-free campus policy: } \\
\text { About half of the respondents knew that there was a } \\
\text { policy on smoking on campus; } 64 \% \text { knew that the policy } \\
\text { banned smoking anywhere on campus }\end{array}$ & \\
\hline $\begin{array}{l}\text { Martínez et al. } \\
(2016)^{36}\end{array}$. & 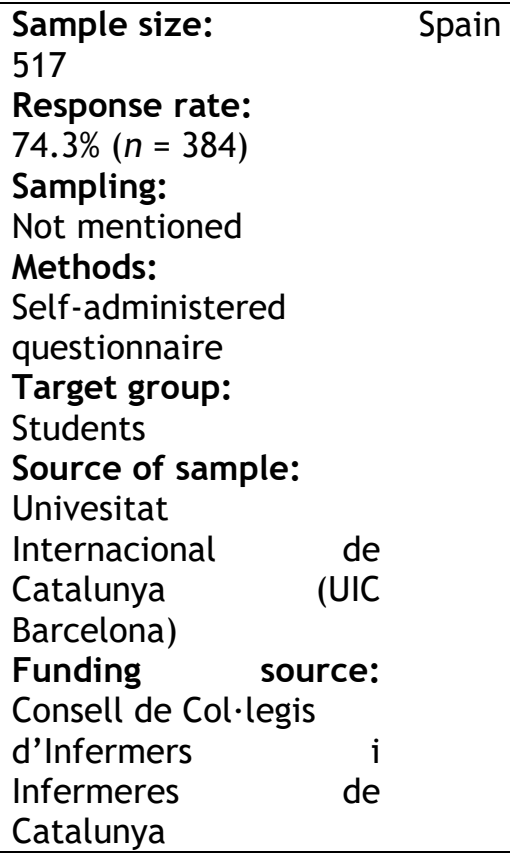 & $\begin{array}{l}\text { Assess attitudes } \\
\text { towards the extension } \\
\text { of outdoor smoke-free } \\
\text { areas on university } \\
\text { campuses }\end{array}$ & $\begin{array}{l}\text { SHS } \\
\text { Most respondents reported exposure to smoke on campure: } \\
\text { Non-smokers were exposed to SHS in outdoor areas where } \\
\text { smoking was allowed } \\
\text { Attitudes towards a smoke-free campus: } \\
\text { The majority of respondents reported believing that the } \\
\text { university complied with the indoor smoking ban, but } \\
\text { fewer agreed on the compliance with the outdoor ban } \\
\text { Smoking behavior: } \\
\text { Outdoor smoke-free policies were associated with a drop } \\
\text { in student smoking rates } \\
\text { Support for a smoke-free campus: } \\
\text { The respondents (majority was non-smokers) expressed } \\
\text { strong support for indoor smoke-free policies; however, } \\
\text { only 39.3\% of participants supported regulating outdoor } \\
\text { smoking for university campuses }\end{array}$ & $\begin{array}{l}\text { Mostly due to the use of a } \\
\text { self-administered } \\
\text { questionnaire, } \\
\text { exposure data were self- } \\
\text { reported and did not use } \\
\text { biomarkers for detecting } \\
\text { exposure; cross-sectional } \\
\text { study design; did not } \\
\text { assess socioeconomic } \\
\text { status, which would have } \\
\text { been useful for adjusting } \\
\text { the analysis for this } \\
\text { variable; selection bias } \\
\text { could not be ruled out, } \\
\text { given that 25\% of } \\
\text { registered students did not } \\
\text { attend class on the day the } \\
\text { survey was conducted }\end{array}$ \\
\hline $\begin{array}{l}\text { Hall et al. } \\
(2015)^{27}\end{array}$ & $\begin{array}{l}\text { Sample size: } \\
462 \\
\text { Response rate: }\end{array}$ & $\begin{array}{l}\text { Assess attitudes } \\
\text { among various college } \\
\text { campus populations }\end{array}$ & $\begin{array}{l}\text { Attitudes towards a smoke-free campus: } \\
\text { Male respondents were less likely than female } \\
\text { respondents to oppose the feasibility of designated }\end{array}$ & $\begin{array}{l}\text { Participants were } \\
\text { volunteers rather than a } \\
\text { random sample (may have }\end{array}$ \\
\hline
\end{tabular}




\begin{tabular}{|c|c|c|c|c|}
\hline & $\begin{array}{l}\text { Not applicable } \\
\text { Sampling: } \\
\text { Convenience sampling } \\
\text { Methods: } \\
\text { Web-based survey } \\
\text { Target group: } \\
\text { Students } \\
\text { employees and } \\
\text { Source of sample: } \\
\text { Southeastern University } \\
\text { Funding source: } \\
\text { Not mentioned } \\
\end{array}$ & $\begin{array}{l}\text { relative to smoking, } \\
\text { SHS exposure, and the } \\
\text { acceptability of } \\
\text { campus tobacco } \\
\text { policies for developing } \\
\text { effective, targeted } \\
\text { implementation } \\
\text { strategies }\end{array}$ & $\begin{array}{l}\text { smoking areas; staff members were more likely than } \\
\text { students to agree with policy development and } \\
\text { enforcement } \\
\text { Attitudes towards smoking: } \\
\text { Female respondents were more likely to report being } \\
\text { bothered by SHS, along with a stronger belief in the } \\
\text { dangers associated with SHS } \\
\text { Smoking behavior: } \\
\text { Older respondents may have had more experience with } \\
\text { attempts at quitting and recognized the need for } \\
\text { assistance when making this behavior change }\end{array}$ & $\begin{array}{l}\text { introduced selection bias); } \\
\text { "tobacco use" as } \\
\text { delimited to smoking } \\
\text { cigarettes, which is a } \\
\text { subset of tobacco use } \\
\text { behavior }\end{array}$ \\
\hline $\begin{array}{l}\text { Berg et al. } \\
(2011)^{30}\end{array}$ & $\begin{array}{l}\text { Sample size: } \\
\text { Online survey: } 8,834 \\
\text { Focus group discussion: } \\
73 \\
\text { Response rate: } \\
30.6 \% \quad(n=2,700) \text { : } \\
\text { online survey } \\
\text { Sampling: } \\
\text { Random sampling } \\
\text { Methods: } \\
\text { Mix method (online } \\
\text { survey and focus group } \\
\text { discussion) } \\
\text { Target group: } \\
\text { Students } \\
\text { Source of sample: } \\
\text { Two colleges in the } \\
\text { Midwest } \\
\text { Funding source: } \\
\text { ClearWay Minnesota }\end{array}$ & $\begin{array}{l}\text { Examine attitudes } \\
\text { regarding public and } \\
\text { campus smoke-free } \\
\text { policies, the } \\
\text { implementation of } \\
\text { private policies, and } \\
\text { specific factors related } \\
\text { to reactions to smoke- } \\
\text { free policies among } \\
\text { students at a 2-year } \\
\text { college and a 4-year } \\
\text { university }\end{array}$ & $\begin{array}{l}\text { SHS exposure: } \\
\text { The vast majority recognized the impact of the policies } \\
\text { on reducing SHS exposure } \\
\text { Attitudes towards a smoke-free campus: } \\
\text { The respondents reported concern about the appearance } \\
\text { of their campuses and believed that more smoking } \\
\text { restrictions would result in improved campus cleanliness. } \\
\text { Their concerns also included the burden these policies } \\
\text { imposed on smokers, and difficulty enforcing the rules } \\
\text { Smoking behavior: } \\
\text { Smokers generally approved of the ban because of its } \\
\text { impact on reducing smoking } \\
\text { Support for a smoke free campus: } \\
\text { Most respondents strongly supported smoke-free policies } \\
\text { in public, on campus, and in private spaces }\end{array}$ & $\begin{array}{l}\text { It included two colleges in } \\
\text { the Midwest, and may not } \\
\text { reflect the demographics } \\
\text { of US colleges, thus } \\
\text { limiting generalizability; } \\
\text { the high rates of support } \\
\text { for smoke-free policies } \\
\text { might be reflective of the } \\
\text { sample's } \\
\text { socioeconomic higher } \\
\text { background; details } \\
\text { regarding the nature of } \\
\text { the respondents' } \\
\text { homes/dwellings were not } \\
\text { assessed; smoking status } \\
\text { was assessed using self- } \\
\text { report and may have } \\
\text { resulted in biased } \\
\text { reporting; the cross- } \\
\text { sectional nature of the } \\
\text { data did not allow } \\
\text { causality to be determined }\end{array}$ \\
\hline
\end{tabular}


Table 2. A summary of the variables investigated in the studies.

\begin{tabular}{|c|c|c|c|c|c|c|c|}
\hline \multirow[t]{2}{*}{ Study } & \multicolumn{7}{|c|}{ Variable } \\
\hline & $\begin{array}{l}\text { SHS } \\
\text { exposure }\end{array}$ & $\begin{array}{l}\text { Attitudes } \\
\text { towards a } \\
\text { smoke-free } \\
\text { campus } \\
\text { policy }\end{array}$ & $\begin{array}{l}\text { Attitudes } \\
\text { towards } \\
\text { smoking }\end{array}$ & Smoking behavior & $\begin{array}{l}\text { Support } \\
\text { for a } \\
\text { smoke- } \\
\text { free } \\
\text { campus }\end{array}$ & $\begin{array}{l}\text { Behavior towards } \\
\text { smoking }\end{array}$ & $\begin{array}{l}\text { Awareness of } \\
\text { smoke-free } \\
\text { campus } \\
\text { policy }\end{array}$ \\
\hline Wong et al. $(2020)^{20}$ & $\Gamma$ & $\sqrt{5}$ & & 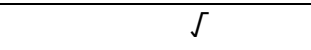 & 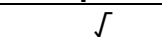 & & \\
\hline $\begin{array}{l}\text { Feldman et al. } \\
(2016)^{21}\end{array}$ & r & r & & r & r & & \\
\hline Gatto et al. $(2018)^{22}$ & r & r & & r & & 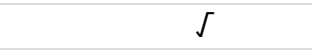 & 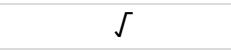 \\
\hline Almutairi (2014) & & & S & 厂 & 厂 & & \\
\hline $\begin{array}{l}\text { Chaaya et al. } \\
(2015)^{31}\end{array}$ & & L & & r & r & & \\
\hline Burns et al. $(2016)^{28}$ & 厂 & 厂 & S & 厂 & 厂 & & 厂 \\
\hline $\begin{array}{l}\text { Lechner et al. } \\
(2014)^{33}\end{array}$ & $\zeta$ & & 2 & r & & & \\
\hline Butler et al. (2012) & & 厂 & & S & S & & \\
\hline $\begin{array}{l}\text { Gauthier et al. } \\
(2013)^{23}\end{array}$ & L & & 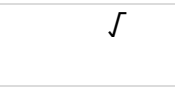 & L & & $\tau$ & \\
\hline $\begin{array}{l}\text { Ramachandran et al. } \\
(2020)^{34}\end{array}$ & r & & S & r & r & & \\
\hline Gong et al. $(2016)^{35}$ & r & & S & $\sqrt{2}$ & & & \\
\hline $\begin{array}{l}\text { Bartington et al. } \\
(2020)^{24}\end{array}$ & & S & s & 厂 & 厂 & & \\
\hline Wray et al. (2020) $)^{25}$ & & S & S & S & S & & \\
\hline Bamashmous (2018) ${ }^{26}$ & S & S & S & 厂 & 厂 & & S \\
\hline $\begin{array}{l}\text { Martínez et al. } \\
(2016)^{36}\end{array}$ & L & L & & r & L & & \\
\hline Hall et al. (2015) $)^{27}$ & & 厂 & $\checkmark$ & $\checkmark$ & & & \\
\hline Berg et al. $(2011)^{30}$ & S & S & & S & S & & \\
\hline
\end{tabular}


All ten studies that examined the attitudes towards smoking reported negative attitudes towards smoking ${ }^{23-28,32,33,35}$. In those studies, the respondents believed that smoking is an annoying habit, bad for health, unacceptable social practice, and that cigarette smoke is suffocating. With reference to the TPB, negative attitudes toward smoking are a good indicator, as they assume smoking is bad practice and therefore can predict the respondent's behavior in complying with the smoke-free policy ${ }^{15}$.

Eight studies reported a positive impact for smoking behaviors among smokers $^{23,25,27,28,30,32,33,36}$, whereas six studies reported negative impacts ${ }^{21,22,26,29,34,35}$; three studies reported mixed negative and positive impacts $^{20,24,31}$. Positive behaviors help smokers quit smoking, attempt to quit smoking, plan to quit smoking, and reduce daily cigarette consumption. There were also smokers with negative behaviors who felt that the policy did not have a positive impact on them to quit smoking, and they continued to smoke on campus and litter their cigarette butts on campus. All 11 studies that measured SHS exposure 20,21,36,22,23,26,28,30,33-35 reported that respondents were still exposed to SHS at university as a consequence of smokers' negative behaviors; in seven studies, more than $50 \%$ of the respondents were exposed to

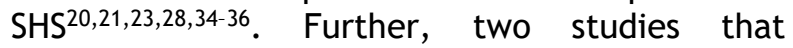
measured the behaviors towards smoking reported that more than $60 \%$ of respondents would not approach and reprimand smokers to stop smoking and adhere to smoke-free campus policy ${ }^{22,23}$. The uncertainty on how smokers should be reprimanded and the desire to avoid confrontation between the respondents and smokers were the respondents' reasons for why they avoided approaching smokers.

Twelve studies evaluated the support and awareness of the smoke-free campus policy. All 12 studies reported positive support, especially the banning of smoking in university buildings ${ }^{20,21,34,36,24-26,28-32}$. Nevertheless, the support differed between smokers and nonsmokers and later contributed to the supporting majority as compared to support from the smokers. Three studies on awareness $22,26,28$ reported that the majority of respondents knew about the existence of the smoke-free campus policy, and more than $60 \%$ of respondents managed to answer questions regarding the policy correctly ${ }^{22}$. One study reported a strong relation between awareness of the policy and support of a smoke-free campus ${ }^{21}$. Higher awareness of the smoke-free campus policy increased support for the policy.

\section{LIMITATIONS}

One limitation of this review is that the literature search was conducted using electronic databases to which our university is subscribed. It is possible that we might have missed some important studies. Further, the studies reviewed were from January 2010 to December 2020, and we assumed that studies prior to this date were irrelevant to the latest practice. The effectiveness of the impact of the smoke-free campus policy on smokers' attitudes and behaviors might differ between the studies included in this review, as some studies did not report the policy in detail or report the duration the policy had been implemented prior to the study being conducted. Lastly, the smoke-free campaign was launched not only in universities, but also more in public domains that every community can access. It is possible that the impact of attitudes towards a smoke-free campus and smoking behavior was not solely influenced by the smoke-free campus policy.

\section{CONCLUSIONS}

Despite the limitations of the study, we have presented a review of studies from all over the world regarding attitudes towards the smoke-free campus policy and smoking behavior, as compared to the review by Dilliott et al. ${ }^{37}$, which focused only on North American universities. We found that the smoke-free campus policy can influence smokers' behavior in reducing smoking activities in the university, subsequently achieving the policy's goal of preventing SHS exposure. Some areas can be improved during the implementation to increase the impact of the policy. The majority of the studies reported positive impacts on smoking behavior; however, all of the studies reported that SHS exposure persisted and that cigarette butts were still found on campus due to smokers obstinately smoking on university grounds in hidden or isolated areas, for example, toilets, back alleys, staircases, or fences ${ }^{38}$. Thus, to increase the effectiveness of the policy, the responsible party of the university should tighten enforcement, intensify the promotion of awareness of the policy, and provide counselling services or quit smoking clinics to aid smokers in quitting smoking.

\section{ACKNOWLEDGEMENTS}

None.

\section{CONFLICT OF INTEREST}

None.

\section{FUNDING}

This research received no specific grant from any funding agency in the public, commercial, or notfor-profit sectors 


\section{REFERENCES}

1. Centers for Disease Control and Prevention (US), U.S. Department of Health and Human Services. The Health Consequences of Involuntary Exposure to Tobacco Smoke: A Report of the Surgeon General. Atlanta,

ncbi.nlm.nih.gov/books/NBK44324/ (2006).

2. World Health Organization. WHO global report on trends in prevalence of tobacco smoking, https: / /apps.who.int/iris/bitstream /handle/10665/156262/97892415649 22_eng.pdf; jsessionid $=18318 D E 7 B 3 C$ 3CE50967CF3B71C8B4B5D?sequence $=$ 1. (2015).

3. CDC's Office on Smoking and Health. Smoking and Tobacco Use; Fact Sheet; Health Effects of Secondhand Smoke. $C D C$, https: / /www.cdc.gov/tobacco/data _statistics/fact_sheets/secondhand_ smoke/health_effects/ (2014, accessed 1 July 2020).

4. World Health Organization. WHO report on the global tobacco epidemic, 2011: warning about the dangers of tobacco, https: / /www. who.int/tobacco/glob al_report/2011/en/ (2011).

5. Jha $P$, Ramasundarahettige $C$, Landsman V, et al. 21st-century hazards of smoking and benefits of cessation in the United States. N Engl J Med 2013; 368: 341-350.

6. World Health Organization. WHO Framework Convention on Tobacco Control. Geneva, https: / /apps.who.int/iris/bitstream /handle/10665/42811/9241591013.p df?sequence $=1$ (2005).

7. Jasni $\mathrm{NH}$, Omar $M$, Awang $\mathrm{R}$, et al. Impact of Smoke Free Melaka City Project on Perception, Attitude and Behaviour of People in Melaka. 2012.

8. Fichtenberg CM, Glantz SA. Effect of smoke-free workplaces on smoking behaviour: Systematic review. $\mathrm{Br}$ Med J 2002; 325: 1-7.

9. Coughlin SS, Anderson J, Smith SA. Legislative smoking bans for reducing exposure to secondhand smoke and smoking prevalence: Opportunities for Georgians. J Georg Public Heal Assoc 2015; 5: 2-7.

10. Creamer MLR, Wang TW, Babb S, et al. Tobacco Product Use and Cessation Indicators Among Adults United States, 2018. MMWR Morb Mortal Wkly Rep 2019; 68: 10131019.

11. US Department of Health and Human Services. The Health Consequences of Smoking-50 Years of Progress A Report of the Surgeon General. Atlanta, https://www.ncbi.nlm.nih.gov/book s/NBK179276/\#: :text=Fifty years have passed since, and death caused by smoking. (2014).

12. Peto $R$, Darby $S$, Deo $H$, et al. Smoking, smoking cessation, and lung cancer in the UK since 1950: Combination of national statistics with two case-control studies. $\mathrm{Br}$ Med J 2000; 321: 323-329.

13. US Department of Health and Human Services. Preventing tobaco use among youth and young adults: $A$ report of the surgeon general. Atlanta: Centers for Disease Control and Prevention (US), https: //www.ncbi.nlm.nih.gov/book s/NBK99237/ (2016).

14. American Nonsmokers' Rights Foundation. Smokefree and TobaccoFree U . S . and Tribal Colleges and Universities. 2019.

15. Record RA. Tobacco-Free Policy Compliance Behaviors among College Students: A Theory of Planned Behavior Perspective. J Health Commun 2017; 22: 562-567.

16. Ajzen I. The theory of planned behavior. Organ Behav Hum Decis Process 1991; 50: 179-211.

17. Ajzen I. Attitudes, traits, and actions: Dispositional prediction of behavior in personality and social psychology. Adv Exp Soc Psychol 1987; 20: 1-63.

18. Fishbein M, Ajzen I. Predicting and changing behavior: The reasoned action approach. 1st Editio. New 
York: Taylor and Francis Group, 2011. Epub ahead of print 2011. DOI: $10.4324 / 9780203838020$.

19. Moher D, Liberati A, Tetzlaff J, et al. Preferred Reporting Items for Systematic Reviews and MetaAnalyses: the PRISMA statement. $\mathrm{Br}$ Med J 2009; 8: 336-341.

20. Wong SL, Epperson AE, Rogers J, et al. A multimodal assessment of tobacco use on a university campus and support for adopting a comprehensive tobacco-free policy. Prev Med (Baltim); 133. Epub ahead of print 2020. DOI: 10.1016/j.ypmed.2020.106008.

21. Feldman I, Donchin M, Levine H. A smoke-free medical campus in Jerusalem: Data for action. Isr J Health Policy Res; 5. Epub ahead of print 2016. DOI: 10.1186/s13584-0160080-9.

22. Gatto A, Powell SE, Walters EF, et al. A Mixed-Methods Assessment of a Peer-Enforced Tobacco- and SmokeFree Policy at a Large Urban University. J Community Health 2019; 44: 365-376.

23. Gauthier AP, Dorman SC, Wenghofer $\mathrm{EF}$, et al. Recommendations for Tobacco Control on Post-Secondary Campuses that are Geographically Isolated. Heal Promot Perspect 2013; 3: 175-184.

24. Bartington SE, Wootton R, Hawkins $P$, et al. Smoking behaviours and attitudes towards campus-wide tobacco control policies among staff and students: A cross-sectional survey at the University of Birmingham. BMC Public Health; 20. Epub ahead of print 2020. DOI: 10.1186/s12889-020-8321-9.

25. Wray RJ, Hansen N, Ding D, et al. Effects of a campus-wide tobaccofree policy on tobacco attitudes, norms and behaviors among students, staff and faculty. J Am Coll Heal 2020; 0: 1-12.

26. Bamashmous $M$. Determinants of support for a smoke-free university policy. J Contemp Dent Pract 2018; 19: 799-807.

27. Hall ME, Williams RD, Hunt B.
Assessment of Attitudes Regarding Tobacco-Free Campus Policy and Secondhand Smoke Exposure Among College Students, Faculty, and Staff. Am J Heal Educ 2015; 46: 48-57.

28. Burns S, Hart E, Jancey J, et al. A cross sectional evaluation of a total smoking ban at a large Australian university. BMC Res Notes; 9. Epub ahead of print 2016. DOI: 10.1186/s13104-016-2090-7.

29. Butler KM, Rayens MK, Hahn EJ, et al. Smoke-Free Policy and Alcohol Use Among Undergraduate College Students. Public Health Nurs 2012; 29: 256-265.

30. Berg CJ, Lessard L, Parelkar PP, et al. College student reactions to smoking bans in public, on campus and at home. Health Educ Res 2011; 26: 106118.

31. Chaaya M, Alameddine M, Nakkash R, et al. Students' attitude and smoking behaviour following the implementation of a university smoke-free policy: A cross-sectional study. BMJ Open; 3. Epub ahead of print 2013. DOI: $10.1136 /$ bmjopen2012-002100.

32. Almutairi KM. Attitudes of Students and Employees Towards the Implementation of a Totally Smoke Free University Campus Policy at King Saud University in Saudi Arabia: A Cross Sectional Baseline Study on Smoking Behavior Following the Implementation of Policy. J Community Health 2014; 39: 894900.

33. Lechner W V., Meier E, Miller MB, et al. Changes in smoking prevalence, attitudes, and beliefs over 4 years following a campus-wide antitobacco intervention. J Am Coll Heal 2012; 60: 505-511.

34. Ramachandran S, Bentley S, Casey E, et al. Prevalence of and factors associated with violations of a campus smoke-free policy: A crosssectional survey of undergraduate students on a university campus in the USA. BMJ Open; 10. Epub ahead of print $2020 . \quad$ DOI: 10.1136/bmjopen-2019-030504.

35. Gong $M$, Liang ZY, Zhang $Y Y$, et al. 
Implementation of the tobacco-free campus policy on college campuses: Evidence from a survey of college students in Beijing. Nicotine Tob Res 2016; 18: 2083-2091.

36. Martínez C, Méndez C, Sánchez M, et al. Attitudes of students of a health sciences university towards the extension of smoke-free policies at the university campuses of Barcelona (Spain). Gac Sanit 2017; 31: 132-138.

37. Dilliott D, Fazel S, Ehsan N, et al. The attitudes and behaviors of students, staff and faculty towards smoke-free and tobacco-free campus policies in North American universities: A narrative review. Tob Prev Cessat 2020; 6: 47.

38. Jancey J, Bowser N, Burns S, et al. No smoking here: Examining reasons for noncompliance with a smoke-free policy in a large university. Nicotine Tob Res 2014; 16: 976-983. 